\title{
The Family Approach for Scaling Out of Leaf Colour Chart Based Nitrogen Management in Rice
}

\author{
M. HARUnur Rashid ${ }^{1 *}$, M. A. Hossain Khan ${ }^{2}$ AND M. Murshedul Alam ${ }^{3}$ \\ ${ }^{1 \& 2}$ Rice Farming Systems Division, Bangladesh Rice Research Institute, Gazipur, Bangladesh \\ ${ }^{3}$ International Rice Research Institute Bangladesh Office, Dhaka, Bangladesh
}

\begin{abstract}
In the traditional technology transfer process, the role of active participation of family members, immediate to household head, is not considered. Two sets of target audiences, lead farmers for the traditional method and family members for the family approach were trained to evaluate the expansion scenario of Leaf Colour Chart ( $L C C$ ) based nitrogen management in rice. In the family approach (FA), young sons or brothers of the farmers helped in demonstrating the new technology and adoption by participating in the field activities directly. On the other hand, young daughters and wife helped in keeping the LCC in a safe place, reminded the farmers about the fertilizer rate and date for taking LCC readings and timely application of nitrogen following LCC use guidelines. On an average, each trained family shared knowledge on the technology with 6.2 neighbouring farmers whereas 2.03 farmers were informed by each lead farmer. The technology adoption was enhanced remarkably due to participation of family members. The higher rate of adoption of FA technology by the neighboring farmers compared to Lead Farmer Approach (LFA) proved its cost effectiveness.
\end{abstract}

Key words: Leaf colour chart, rice, cost-effectiveness.

\section{INTRODUCTION}

Technology dissemination to and adoption by end users (farmers) depend on many factors like nature of technology, farmers' knowledge and resource bases, demand for technology, cost effectiveness of technology and uptake pathway used for dissemination

\section{The Family approach for Scaling out of Technology in rice}

(Jabbar et al., 2003). All these factors are needed to be considered for narrowing the adoption gap of technology (Choudhary and Vijayaraghavan, 2004). In Bangladesh, the Department of Agriculture Extension (DAE) has been disseminating technologies following traditional (existing) methods, which includes demonstration, farmers' trainings and meetings and field days. In this method, household heads or lead farmers are considered as key persons for any kind of communication for technology dissemination. The participation of family members immediate to the lead farmers or household heads is usually not accounted in the traditional technology transfer process. On the other hand, in many cases head of farm family practically is not involved in agriculture or his decision is somehow influenced or overruled by other members of the family.

\footnotetext{
* Corresponding author: Senior Scientific Officer, Rice Farming Systems Division, BRRI, Gazipur 1701. Phone: 9257401-5 Extn. 226 (res.), Mobile: 01716-950421, Fax: 9261110, E-mail: hrashid67@yahoo.com

(C) 2006 School of Agriculture and Rural Development, Bangladesh Open University, All rights reserved.
} 
Crop production involves a series of operations to produce outputs from a crop. All family members take part in the production and post-harvest processing of crops. Additionally, farm families have different systems for determining intra-household labor allocation. The Wheat Research Center (WRC) of Bangladesh Agricultural Research Institute (BARI) and the International Maize and Wheat Improvement Center (CIMMYT) have developed a gender and task unbiased Whole Family Training Program for post harvest technologies of wheat (Meisner et al. 2002). Later they extended this approach to overall wheat and maize production and higher degrees of adoption of technologies was marked by CIMMYT.

Rice is the synonym of food or livelihood security. Whole Family Approach is not tested in rice production yet. This approach might be conducive in dissemination of new rice production technologies like LCC-based nitrogen management and needs validation.

Fertilizer is an important input in modern agriculture and accounts $15 \%$ of total costs of rice production. Among the fertilizers used in rice production, urea is the highest in quantity in the country. Alam et al. (2004) recommended Leaf Colour Chart (LCC) for judicious use of nitrogen in rice cultivation. Khan et al. (2004) reported that LCC-based nitrogen application increased the grain yield and reduced the urea use over farmers' practice. Therefore, the present study was undertaken with a view to evaluating two uptake pathways, (traditional and family approach) for scaling out the LCC-based nitrogen management in rice.

\section{MATERIALS AND METHODS}

\section{Technology}

Guidelines for LCC use have been presented in Table 1. The LCC is a diagnostic tool of measuring leaf color in situ in the field and to determine the right time of $\mathrm{N}$ topdressing in rice. It is like a ruler made of high-quality plastic and consists of four-color panels or shades from light yellowish green (No. 2) to dark green (No. 5). The color panels are fabricated with veins resembling rice leaves. The color panels are used as reference for identifying the optimal leaf color that needs to be maintained throughout the crop cycle to obtain higher yields. The optimal leaf color varies depending on variety and crop establishment technique and is termed as critical LCC value (Balasubramanian et al. 1999). Farmers need to apply $\mathrm{N}$ fertilizer (urea) when leaf color falls below the critical value.

Table 1. LCC use guidelines

\begin{tabular}{|c|c|c|c|c|c|}
\hline \multirow{3}{*}{\multicolumn{2}{|c|}{ Item }} & \multicolumn{4}{|c|}{ Recommendation } \\
\hline & & \multicolumn{2}{|c|}{ Aman rice } & \multicolumn{2}{|c|}{ Boro rice } \\
\hline & & Transplanted rice & Seeded rice & Transplanted rice & Seeded rice \\
\hline (1) & LCC critical value & 3.5 & 3.0 & 3.5 & 3.0 \\
\hline (2) & $\begin{array}{l}\text { Starting for LCC } \\
\text { reading }\end{array}$ & $\begin{array}{l}15 \text { days after } \\
\text { transplanting }\end{array}$ & $\begin{array}{l}15 \text { days after } \\
\text { seeding }\end{array}$ & $\begin{array}{l}21 \text { days after } \\
\text { transplanting }\end{array}$ & $\begin{array}{l}25 \text { days after } \\
\text { seeding }\end{array}$ \\
\hline (3) & $\begin{array}{l}\text { When should } \\
\text { stop reading }\end{array}$ & Booting & Booting & Booting & Booting \\
\hline (4) & $\begin{array}{l}\text { Days interval for } \\
\text { LCC reading }\end{array}$ & 10 & 10 & 10 & 10 \\
\hline (5) & $\begin{array}{l}\text { LCC reading in } \\
\text { hill or plant/field }\end{array}$ & $\begin{array}{l}\text { The top most } \\
\text { exposed leaves of } \\
10 \text { hills or plants }\end{array}$ & $\begin{array}{l}\text { The top most } \\
\text { exposed leaves } \\
\text { of } 10 \text { hills or } \\
\text { plants }\end{array}$ & $\begin{array}{l}\text { The top most } \\
\text { exposed leaves of } \\
10 \text { hills or plants }\end{array}$ & $\begin{array}{l}\text { The top most } \\
\text { exposed leaves of } \\
10 \text { hills or plants }\end{array}$ \\
\hline (6) & $\begin{array}{l}\text { Urea application } \\
\text { time }\end{array}$ & $\begin{array}{l}\text { If LCC reading of } 6 \\
\text { or more leaves fall } \\
\text { below critical } \\
\text { value. }\end{array}$ & $\begin{array}{l}\text { If LCC reading } \\
\text { of } 6 \text { or more } \\
\text { leaves fall below } \\
\text { critical value. }\end{array}$ & $\begin{array}{l}\text { If LCC reading of } 6 \\
\text { or more leaves fall } \\
\text { below critical } \\
\text { value. }\end{array}$ & $\begin{array}{l}\text { If LCC reading of } 6 \\
\text { or more leaves fall } \\
\text { below critical } \\
\text { value. }\end{array}$ \\
\hline (7) & Urea rate & $\begin{array}{l}7.5 \mathrm{~kg} / \mathrm{bigha}(33 \\
\text { decimal) }\end{array}$ & $\begin{array}{l}7.5 \mathrm{~kg} / \mathrm{bigha}(33 \\
\text { decimal) }\end{array}$ & $\begin{array}{l}9 \mathrm{~kg} / \mathrm{bigha} \text { (33 } \\
\text { decimal) }\end{array}$ & $\begin{array}{l}9 \mathrm{~kg} / \mathrm{bigha} \text { (33 } \\
\text { decimal) }\end{array}$ \\
\hline
\end{tabular}




\section{Selection of site and farmer}

In collaboration with DAE, two villages in each Sadar Upazila of Chuadanga, Meherpur and Jhenaidah districts were purposively selected for comparing two uptake pathways. Ten farm families from each of village for family approach (FA) and 16 lead/ key farmers for traditional method were selected based on group discussion with farmers and extension providers. For both groups, attempts were made to limit the selection to the farmers considering farm size and rice provisioning ability. Information on farmers selected under LFA and FA has been given in Table 2. In FA, three members engaged in farming of which at least one female per family were selected to participate in the training program. In total, forty eight lead farmers (male) under traditional method designed as lead farmer approach (LFA) and ninety family members of FA were invited to participate in the training program.

\section{Training of lead farmers and family members}

The lead/key farmers and family members received training from extension personnel in presence of researcher on how to use LCC for N management in rice. The DAE field workers in the area were also trained with the farmers during May-June 2003.

Before starting the establishment of demonstration, follow up meetings were arranged at all sites. In the meeting, lead farmers of LFA and concerned members of FA were asked to recall different aspects of technology. They were requested to set up demonstration in their fields with LCC-based $\mathrm{N}$ versus existing farmer's $\mathrm{N}$ management in T. Aman rice, 2003. The farmers and the family members established demonstrations on LCC-based $\mathrm{N}$ along with existing farmers' $\mathrm{N}$ management placing in two sub-plots within a bigger plot. Bund was erected between two sub-plots to check the lateral movements of $\mathrm{N}$.

\section{Monitoring and data collection}

Monitoring was done maintaining close contact with the farmers. Data were collected through structured data sheet prepared by the researchers. Technology validation and adoption were monitored by the field level staff of research and extension team and data were recorded. Data were collected on the several measurable indicators: a) grain yield, b) degree of technology adoption (day interval for LCC reading, amount of $\mathrm{N}$ applied, date of $\mathrm{N}$ applied following LCC reading and man involved in LCC reading taking) and c) expansion of technology (number of neighboring farmers validated and adopted the technology and area coverage under participating and neighboring farmers).

Crop cut was done in the demonstrated fields of farmers under LFA and FA and yield was calculated in presence of participating and neighboring farmers/ family members. In the farmers' gathering after the harvest of the crop, the participating and neighboring farmers for both methods also reported their yields in local unit. The data were analyzed and presented in two way tables.

\section{RESULTS AND DISCUSSION}

\section{Farmers' knowledge and attitude}

Focal group meetings were organized at each site for having information on farmers' understanding and behavior towards technology. Some 92 farmers under LFA received the training and finally 83 participated in conducting demonstration season (Table 2).

Table 2. Farmers trained and took part in evaluation of LCC-based $\mathbf{N}$ under two uptake pathways

\begin{tabular}{|c|c|c|c|c|c|c|}
\hline \multirow[t]{2}{*}{ Site } & \multirow[t]{2}{*}{ District } & \multirow{2}{*}{$\begin{array}{l}\text { No. of farmers/ } \\
\text { family members } \\
\text { invited for training }\end{array}$} & \multicolumn{3}{|c|}{$\begin{array}{l}\text { No. of farmers/ family members } \\
\text { attended training }\end{array}$} & \multirow{2}{*}{$\begin{array}{c}\text { No. of farmers/ farms } \\
\text { participated in technology } \\
\text { demonstration }\end{array}$} \\
\hline & & & Male & Female & Total & \\
\hline \multicolumn{7}{|c|}{ Lead Farmer Approach (LFA) } \\
\hline Alookdia & Chuadanga & 16 & 16 & 0 & $16(100)$ & $14(88)$ \\
\hline Alampur & Meherpur & 16 & 12 & 0 & $12(75)$ & $12(75)$ \\
\hline Badpukuria & Jhenaidah & 16 & 16 & 0 & $16(100)$ & $14(88)$ \\
\hline \multicolumn{2}{|c|}{ Total } & 48 & 44 & 0 & $44(92)$ & $40(83)$ \\
\hline \multicolumn{7}{|c|}{ Family Approach (FA) } \\
\hline Bhatia & Chuadanga & 30 & 18 & 12 & $30(100)$ & $10(100)$ \\
\hline Mohajanpur & Meherpur & 30 & 20 & 10 & $30(100)$ & $10(100)$ \\
\hline Holydhani & Jhenaidah & 30 & 18 & 12 & $30(100)$ & $10(100)$ \\
\hline \multicolumn{2}{|c|}{ Total } & 90 & 56 & 34 & $90(100)$ & $30(100)$ \\
\hline
\end{tabular}

Figure in parentheses indicate the percentage 
Similar finding was also reported by Meisner et al. (2003). For the case of FA 34 females attended the training program with 56 male members of the families. Trained women did not take part in field activities but they participated in the post-harvest operations. Women were found in reminding male members of the family for performing operations timely. Neighboring farmers or relatives coming to their houses became aware of LCC use.

Table 3 indicates that family members were found better oriented on technology compared to farmers belonged to LFA. It appeared that $93 \%$ percent farmers under FA were able to explain the technology as against of $64 \%$ for the LFA. This means that family members became more interested regarding technology because they had better scope for discussing among themselves any lacking freely as they did not feel shy while practicing measuring leaf color with LCC. Farmers' attitude towards technology was highly positive and 100\% farmers of FA showed positive response and they used LCC in the other plots. This result agrees well with the finding of Meisner et al. (2003). In case of LFA, $65 \%$ farmers responded positively and finally only $52 \%$ adopted LCC based $\mathrm{N}$ management in plots other than demonstration.

Table 3. Knowledge and attitude towards technology (LCC-N) under two uptake pathways

\begin{tabular}{ccccc}
\hline District & $\begin{array}{c}\text { Uptake } \\
\text { pathway }\end{array}$ & $\begin{array}{c}\text { Can explain } \\
\text { technology }(\% \\
\text { farmer) }\end{array}$ & $\begin{array}{c}\text { Change attitude to } \\
\text { LCC-N (\% farmer) }\end{array}$ & $\begin{array}{c}\text { Used LCC in their fields } \\
\text { other than } \\
\text { demonstration }\end{array}$ \\
\hline \hline Chuadanga & FA & 97 & 100 & 100 \\
Meherpur & LFA & 56 & 60 & 13 \\
& FA & 93 & 100 & 100 \\
Jhenaidah & LFA & 75 & 75 & 75 \\
& FA & 90 & 100 & 100 \\
Mean & LFA & 60 & 60 & 50 \\
& FA & 93 & 65 & 100 \\
\hline
\end{tabular}

\section{Degree of technology adoption}

\section{Taking of LCC reading}

Recommendation for starting of leaf color measurement by LCC is at 15 DAT in T. Aman rice. In the present study the farmers under FA started taking LCC reading between 13-21 DAT (Table 4). In subsequent measurement, $80 \%$ farmers measured leaf color in time under FA whereas only $40 \%$ of LFA followed the recommendation and $47 \%$ farmers were late to take reading by 2-6 days and $13 \%$ took reading by $1-4$ days earlier.

Table 4: Date of LCC reading taken by farmers under two uptake pathways

\begin{tabular}{|c|c|c|c|c|c|}
\hline \multirow[t]{2}{*}{ District } & \multirow{2}{*}{$\begin{array}{c}\text { Uptake } \\
\text { pathway }\end{array}$} & \multirow{2}{*}{$\begin{array}{l}1^{\text {st }} \mathrm{LCC} \\
\text { reading } \\
\text { taken } \\
\left.(\mathrm{DAT})^{\star}\right)\end{array}$} & \multicolumn{3}{|c|}{ Variation in LCC reading taken } \\
\hline & & & $\begin{array}{c}\text { On recommended } \\
\text { date } \\
\text { (\% farmers) } \\
\end{array}$ & $\begin{array}{l}\text { Days later from } \\
\text { recommended date } \\
\text { (\% farmers) }\end{array}$ & $\begin{array}{l}\text { Days earlier from } \\
\text { recommended date } \\
\text { (\% farmers) }\end{array}$ \\
\hline \multirow{2}{*}{ Chuadanga } & FA & 15 & 80 & 20 (2 days) & - \\
\hline & LFA & $13-20$ & 50 & 40 (2-3 days) & 10 (2 days) \\
\hline \multirow{2}{*}{ Meherpur } & FA & $15-16$ & 80 & 20 (2 days) & - \\
\hline & LFA & $15-20$ & 30 & 50 (1-5 days) & 20 (3-4 days) \\
\hline \multirow{2}{*}{ Jhenaidah } & FA & $14-15$ & 80 & 20 (1 day) & - \\
\hline & LFA & $15-21$ & 40 & 50 (2-6 days) & 10 (1-2 days) \\
\hline \multirow{2}{*}{ Mean } & FA & - & 80 & 20 & - \\
\hline & LFA & - & 40 & 47 & 13 \\
\hline
\end{tabular}

*DAT = Days after transplanting 


\section{Nitrogen fertilizer application}

Table 5 indicates that on an average, 87\% farmers of FA applied $\mathrm{N}$ on recommended date and only $13 \%$ applied 1-2 days later from the recommendation. Farmers of LFA (47\%) delayed by 2-4 days in applying N, 13\% farmers applied 1-4 days earlier and 40\% followed the recommendation.

Table 5. Nitrogen fertilizer application following recommendation time by farmers under two uptake pathways

\begin{tabular}{|c|c|c|c|c|}
\hline District & $\begin{array}{c}\text { Uptake } \\
\text { pathway }\end{array}$ & $\begin{array}{c}\text { On recommended date or } \\
\text { on } L C C \text { reading day } \\
\text { (\% farmers })\end{array}$ & $\begin{array}{l}\text { Days later } \\
\text { recommended date } \\
(\% \text { farmers })\end{array}$ & $\begin{array}{l}\text { Days earlier from } \\
\text { recommended date } \\
(\% \text { farmers })\end{array}$ \\
\hline \multirow{2}{*}{ Chuadanga } & 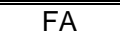 & 90 & 10 (2 days) & - \\
\hline & LFA & 50 & 40 (2-3 days) & 10 (2 days) \\
\hline \multirow{2}{*}{ Meherpur } & FA & 80 & 20 (2 days) & - \\
\hline & LFA & 30 & 50 (2-4 days) & 20 (3-4 days) \\
\hline \multirow{2}{*}{ Jhenaidah } & $\mathrm{FA}$ & 90 & 10 (1 day) & - \\
\hline & LFA & 40 & 50 (2-4 days) & 10 (1-2 days) \\
\hline \multirow{2}{*}{ Mean } & FA & 87 & 13 & - \\
\hline & LFA & 40 & 47 & 13 \\
\hline
\end{tabular}

Variations were also observed in $\mathrm{N}$ rates applied by farmers of two uptake pathways (Table 6). More variability was recorded for LFA, 50 and 13\% farmers applied higher and lower amount of $\mathrm{N}$ compared to recommendation made for LCC, respectively. Only 37\% LFA farmers gave $\mathrm{N}$ to their crops as per recommendation, on the other hand $80 \%$ farmers under FA followed the recommendation.

Table 6. Rate of nitrogen fertilizer used by farmers under two uptake pathways

\begin{tabular}{|c|c|c|c|c|}
\hline \multirow[t]{2}{*}{ District } & \multirow{2}{*}{$\begin{array}{l}\text { Uptake } \\
\text { pathway }\end{array}$} & \multicolumn{3}{|c|}{ Variation in $\mathrm{N}$ fertilizer (urea) application } \\
\hline & & $\begin{array}{c}\text { As per } \\
\text { recommended rate } \\
\text { (\% farmers) }\end{array}$ & $\begin{array}{l}\text { Higher than } \\
\text { recommended rate } \\
\text { (\% farmers) }\end{array}$ & $\begin{array}{l}\text { Lower than recommended } \\
\text { rate (\% farmers) }\end{array}$ \\
\hline \multirow{2}{*}{ Chuadanga } & FA & 80 & $20(2-3 \% N)$ & - \\
\hline & LFA & 60 & $10(6-10 \% N)$ & $30(4-8 \% N)$ \\
\hline \multirow{2}{*}{ Meherpur } & $\mathrm{FA}$ & 80 & $20(4-8 \% N)$ & - \\
\hline & LFA & 20 & $70(10-28 \% \mathrm{~N})$ & $10(5 \% N)$ \\
\hline \multirow{2}{*}{ Jhenaidah } & FA & 80 & $20(6-7 \% N)$ & - \\
\hline & LFA & 30 & $70(10-27 \% \mathrm{~N})$ & - \\
\hline \multirow{2}{*}{ Mean } & FA & 80 & 20 & - \\
\hline & LFA & 37 & 50 & 13 \\
\hline
\end{tabular}

On an average, the average $\mathrm{N}$ use was reduced by 50 and $42 \mathrm{~kg} / \mathrm{ha}$ for FA and LFA, respectively, for LCCN over FPN (Table 7). Table 8 shows that the information recorded in the focal group meetings was almost similar to information collected through field monitoring.

Table 7. Amount of nitrogen applied $\left(\mathrm{kg} \mathrm{ha}^{-1}\right)$ by farmers under farmers' and LCC-based $\mathrm{N}$ for two uptake pathways

\begin{tabular}{cccccc}
\hline District & $\begin{array}{c}\text { Uptake } \\
\text { pathway }\end{array}$ & $\begin{array}{c}\text { Farmers' } \\
\text { practiced N } \\
\text { (FPN) }\end{array}$ & $\begin{array}{c}\text { LCC-based N } \\
\text { (LCCN) }\end{array}$ & $\begin{array}{c}\text { Reduced over } \\
\text { FPN }\end{array}$ & $\begin{array}{c}\text { Reduced for } \\
\text { LCC N over } \\
\text { LFA }\end{array}$ \\
\hline \hline \multirow{2}{*}{ Chuadanga } & FA & 140 & 78 & 62 & 17 \\
& LFA & 138 & 95 & 43 & - \\
Meherpur & FA & 125 & 72 & 53 & 06 \\
& LFA & 138 & 78 & 60 & - \\
Jhenaidah & FA & 118 & 84 & 34 & 10 \\
& LFA & 117 & 94 & 50 & - \\
\hline \multirow{2}{*}{ Mean } & FA & 128 & 89 & 42 & - \\
\hline
\end{tabular}


Table 8. Amount of nitrogen applied ( $\left.\mathrm{kg} \mathrm{ha}^{-1}\right)$ in the neighbouring adopting farmers' plots reported by farmers in focal group meeting under farmers' and LCC-based $\mathrm{N}$ for two uptake pathways

\begin{tabular}{cccccc}
\hline District & $\begin{array}{c}\text { Uptake } \\
\text { pathway }\end{array}$ & $\begin{array}{c}\text { Farmers' practiced } \\
\text { N (FPN) }\end{array}$ & $\begin{array}{c}\text { LCC-based N } \\
\text { (LCCN) }\end{array}$ & $\begin{array}{c}\text { Reduced over } \\
\text { FPN }\end{array}$ & $\begin{array}{c}\text { Reduced for LCC } \\
\text { N over LFA }\end{array}$ \\
\hline \hline \multirow{2}{*}{ Chuadanga } & FA & 140 & 75 & 65 & 03 \\
& LFA & 151 & 78 & 73 & - \\
Meherpur & FA & 155 & 75 & 80 & 10 \\
& LFA & 154 & 85 & 69 & - \\
\multirow{2}{*}{ Jhenaidah } & FA & 154 & 78 & 76 & - \\
& LFA & 168 & 94 & 74 & 10 \\
\hline \multirow{2}{*}{ Mean } & FA & 150 & 76 & 74 & - \\
\hline
\end{tabular}

\section{Technology expansion and family members participation}

Focal group meetings were arranged to know the women participation in technology adoption, involvement of other family members in taking LCC readings, knowledge sharing with and LCC adopted by neighboring farmers and area coverage by participating farmers. Information gathered on the above queries is presented in Table 9. All trained women under FA were reported to participate in technology adoption by keeping LCC in safe place and reminding other male members of the family about timely performing of activities related to LCC N. In case of LFA, this was only $25 \%$. In terms of using LCC by other members of the family, it was $40 \%$ for FA as against of $19 \%$ for LFA. Knowledge sharing with neighboring farmers was $130 \%$ higher with FA compared to LFA because members of the family of FA had a wider scope of contacting neighboring farmers and sharing experiences through personal and family contact. Similar findings were also observed in technology adoption by the neighboring farmers. On an average, 1.3 neighboring farmers were motivated and adopted LCC-N in their rice field by each family ( 0.38 farmers/ trained family member) whereas it was 0.16 farmers by each lead farmer.

Table 9. Family members' participation, knowledge sharing and adoption of the technology under two uptake pathways

\begin{tabular}{|c|c|c|c|c|c|c|}
\hline District & $\begin{array}{c}\text { Uptake } \\
\text { pathway }\end{array}$ & $\begin{array}{c}\text { Women's } \\
\text { participation } \\
\text { in technology } \\
\text { adoption }\end{array}$ & $\begin{array}{c}\text { Other family } \\
\text { members took part } \\
\text { in LCC reading and } \\
\text { recalled fertilizer } \\
\text { rate (\% farmers) } \\
\end{array}$ & $\begin{array}{c}\text { Knowledge } \\
\text { sharing with } \\
\text { neighboring } \\
\text { farmers } \\
\text { (No. of farmers) } \\
\end{array}$ & $\begin{array}{l}\text { Neighboring } \\
\text { farmers } \\
\text { adopted } \\
\text { LCC-N } \\
\text { (No.) } \\
\end{array}$ & $\begin{array}{l}\text { Total area under } \\
\text { LCC other than } \\
\text { demonstration } \\
\text { plot } \\
\text { (ha) } \\
\end{array}$ \\
\hline \multirow{2}{*}{ Chuadanga } & $\overline{F A}$ & 100 & 40 & 75 & 09 & 0.15 \\
\hline & LFA & 20 & - & 25 & 02 & 0.07 \\
\hline \multirow{2}{*}{ Meherpur } & FA & 100 & 50 & 35 & 11 & 0.17 \\
\hline & LFA & 30 & 20 & 16 & 03 & 0.11 \\
\hline \multirow{2}{*}{ Jhenaidah } & FA & 100 & 30 & 75 & 14 & 0.13 \\
\hline & LFA & 25 & 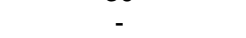 & 41 & 02 & 0.03 \\
\hline \multirow[t]{2}{*}{ Mean } & FA & 100 & 40 & $186^{*}$ & $34^{*}$ & $0.45^{\star}$ \\
\hline & LFA & 25 & 19 & $81^{*}$ & $7^{*}$ & $0.21^{*}$ \\
\hline
\end{tabular}

*Indicate total

\section{Technological advantage}

Grain yield recorded from demonstration plots through crop cut is presented in Table 10. Irrespective of uptake pathways, the grain yield increased with LCC-N in all districts and the average increase for LCC-N over farmers' practiced N (FPN) was 0.42 and $0.20 \mathrm{t} \mathrm{ha}^{-1}$ for FA and LFA, respectively. The higher yield with LCCN was attributed to better $\mathrm{N}$ management options. Difference in the grain yield was also observed between two uptake pathways. On an average, grain yield produced by FA was higher by $0.55 \mathrm{t} \mathrm{ha}^{-1}$. Difference in yield between two uptake pathways was due to deviations made in adopting LCC N recommendation. Farmers in FA adopted LCC recommendation properly which contributed to obtain more yield. Similar results were reported by neighbouring farmers in focal group meeting organized at each site after T. Aman harvest (Table 11). Farmers reported increased grain yield of $0.58 \mathrm{t}$ ha'1 for LCCN with FA over LFA. 
Table 10: Grain yield (t ha ${ }^{-1}$ ) under farmers' and LCC-based $\mathrm{N}$ for two uptake pathways

\begin{tabular}{lccccc}
\hline District & $\begin{array}{c}\text { Uptake } \\
\text { pathway }\end{array}$ & $\begin{array}{c}\text { Farmer's practiced } \\
\text { N (FPN) }\end{array}$ & $\begin{array}{c}\text { LCC-based N } \\
\text { (LCCN) }\end{array}$ & $\begin{array}{c}\text { Increased } \\
\text { over FPN }\end{array}$ & $\begin{array}{c}\text { Increased of yield } \\
\text { for LCCN over LFA }\end{array}$ \\
\hline \hline \multirow{2}{*}{ Chuadanga } & FA & 4.12 & 4.65 & 0.53 & 0.87 \\
\multirow{2}{*}{ Meherpur } & LFA & 3.38 & 3.78 & 0.40 & - \\
& FA & 3.84 & 4.25 & 0.41 & 0.26 \\
\multirow{2}{*}{ Jhenaidah } & LFA & 3.98 & 3.99 & 0.01 & - \\
& FA & 4.25 & 4.56 & 0.31 & 0.51 \\
\multirow{2}{*}{ Mean } & LFA & 3.86 & 4.05 & 0.19 & - \\
& FA & 4.07 & 4.49 & 0.42 & 0.55 \\
\hline
\end{tabular}

Table 11. Grain yield ( $\mathrm{t} \mathrm{ha}^{-1}$ ) reported by farmers' in focal group meeting under farmers and LCC-based $\mathrm{N}$ for two uptake pathways

\begin{tabular}{lccccc}
\hline District & $\begin{array}{c}\text { Uptake } \\
\text { pathway }\end{array}$ & $\begin{array}{c}\text { Farmer's } \\
\text { practiced N (FPN) }\end{array}$ & $\begin{array}{c}\text { LCC-based N } \\
\text { (LCCN) }\end{array}$ & $\begin{array}{c}\text { Increased over } \\
\text { FPN }\end{array}$ & $\begin{array}{c}\text { Increased for } \\
\text { LCCN over LFA }\end{array}$ \\
\hline \hline \multirow{2}{*}{ Chuadanga } & FA & 4.02 & 4.55 & 0.53 & 0.81 \\
& LFA & 3.28 & 3.74 & 0.46 & - \\
\multirow{4}{*}{ Meherpur } & FA & 3.72 & 4.21 & 0.49 & 0.33 \\
& LFA & 3.60 & 3.88 & 0.28 & - \\
& FA & 4.30 & 4.84 & 0.54 & 0.60 \\
\multirow{2}{*}{ Mean } & LFA & 3.87 & 4.24 & 0.37 & - \\
\hline & FA & 4.01 & 4.53 & 0.52 & 0.58 \\
& LFA & 3.58 & 3.95 & 0.37 & - \\
\hline
\end{tabular}

\section{CONCLUSION}

The degree of adoption of technology was very high with FA, more than $80 \%$. Knowledge sharing with the non-trained farmers was $130 \%$ higher for FA over LFA because the family members under FA had a wider scope of contracting neighboring and other farmers and they did enthusiastically through personal and family contract. Productivity under FA was also higher compared to LFA and the difference was attributed to the deviations occurred in degree of adoption of the technology. The technology adoption was enhanced remarkably by the participation of family members with FA.

The findings of the study clearly indicate that there is positive impact of providing training to the farmers through the family approach (FA) on the adoption and dissemination of new technology over the lead farmers approach (LFA). Family approach proved its superiority over the traditional approach in $\mathrm{N}$ management by the use of LCC. Therefore, for effective and rapid dissemination of new rice production technology to the farmers, wider scale validation of FA is suggested.

\section{LITERATURE CITED}

Alam, M. A., Buresh, R. J., Ladha J. K. and Khan, A. H. 2004. "Site specific nutrient management (SSNM) for rice". Bangladesh Rice Research Institute. Gazipur-1701. 32 pp.

Balasubramanian, V., Morales, A. C., Cruz, R. T. and Abdulrachman, S. 1999. On-farm adaptation of knowledgeintensive nitrogen management technologies for rice systems. Nutr. Cycl. Agroecosyst 53, 59-69.

Choudhary, B. N. and Vijayaraghavan, K. 2004. Human resource development and targeted training for accelerated dissemination and adoption of vegetable technologies in India. Food-security and vegetables: a global perspective. pp. 379-388.

Jabbar, M. A., Saleem, M. A. M., Gebreselassie S. and Beyene, H. 2003. Role of knowledge in the adoption of new technologies: an approach and application. International J. Agril. Res., Gov. and Ecol. 2(3-4), 312-327.

Khan, A. H., Rashid, M. H., Alam, M. M., Buresh R. J. and Ladha, J. K. 2004. Nutrient Management for intensive rice-based cropping systems: LCC for $\mathrm{N}$ fertilizer management in rice. In "Proceedings of Technology Development Workshop", held at Bangladesh Rice Research Institute, Gazipur-1707. pp. 52-67.

Meisner, C. A., Sufian, A., Baksh, E., O'-Donoghue M. S., Razzaque, M. A. and Shaha, N. K. 2002. Nongender biased, innovative approaches for accelerated adoption of agricultural technologies. International Maize and Wheat Improvement Center (CIMMYT), Bangladesh.

Meisner, C. A., Sufian, A., Baksh, E., O'-Donoghue, M. S., Razzaque, M. A. and Shaha, N. K. 2003. Whole family training and adoption of innovations in wheat-producing households in Bangladesh. J. Agril. Edu. Extn. 9(4), 165-175. 